\title{
Alternative Fuels for Diesel Engines Using Highly Saturated and Highly Unsaturated Vegetable Oils
}

Ferial A. Zaher, Omayma S. El Kinawy, Hanaa M. Soliman and Adel G. Abdel-Razek*

Fats and Oils Department., National Research Centre, Cairo, Egypt.

\begin{abstract}
7 HE QUALITY of fatty acid methyl esters of linseed oil; ... ..... highly unsaturated oil, as a biodiesel fuel, was compared to that prepared using palm oil; a highly saturated vegetable oil. The comparison included the fuel properties such as the calorific value, flash point, carbon residue $\%$, ash $\%$, pour point, cetane index, viscosity, ASTM distillation characteristics and oxidative stability. The performance of a diesel engine running using $50 \%$ blend of each with regular diesel has been also assessed at different engine loadings and compared to that using regular diesel fuel. The parameters considered in this assessment were the brake specific fuel consumption, the brake thermal efficiency, and the composition of the combustion exhaust The results have shown that biodiesel produced by trans-esterification of linseed oil have two advantages over that produced by trans-esterification of palm oil being more volatile with higher heating value. However, the flash point of linseed biodiesel was lower than that of palm oil biodiesel which makes it less safe during handling and storage. Moreover, linseed biodiesel was much less stable to oxidation than palm oil biodiesel whereby the induction period measured by Rancimat test was 40.6 hours in case of palm biodiesel compared to 2.8 hours in case of linseed. The effect of biodiesel unsaturation on diesel engine performance in terms of fuel consumption rate and brake thermal efficiency was insignificant.
\end{abstract}

Keywords: Biodiesel, Unsaturation, Linseed oil, Palm oil, Oxidative stability.

No doubt that the world energy needs continue to gradually and exponentially increase by time. This is due to the rapid increase in consumption rate of fuel. The most feasible way to solve this problem is through finding renewable fuels alternative to regular petrol fuels. One example of these alternatives is biofuels such as biodiesel which is advantageous over fossil fuels as being more environmentally friendly [1-4]. It should be emphasized that some other advantages of biodiesel over petrodiesel are its high lubricity and the fact that it is biodegradable. Biodiesel can be used to run most vehicles as a blend with regular diesel. The major feedstock for production of biodiesel is plant oil such as soybean, rapeseed and sunflower oils. Biodiesel is considered to be safer than petrol diesel during handling, transportation, and storage $[5,6]$

*Corresponding author e-mail: adelgabr2@gmail.com

DOI: 10.21608/ejchem.2017.685.1016

(C2017 The National Information\& Documentation Center (NIDOC) 
Biodiesel can be prepared by transesterification of vegetable oils which are triacylglycerol with monohydric alcohols especially short chain ones. The reaction can be catalyzed by alkaline or the acidic catalysts such as sodium hydroxide and sulfuric acid respectively [7-9]. Acidic catalysts are preferred whenever the oil acidity is high as the case with used frying oil. Non-catalyzed transesterification is also possible if the reaction occurs at the supercritical conditions of the used alcohol $[10,11]$.

The fatty acid profile of biodiesel is quite similar to that of the feedstock used. Thus, biodiesel fuels derived from different sources can have significantly varying fatty acid profiles and properties. Most important variations in the structure are the degree of unsaturation of fatty acids as well as their chain lengths [12].

Therefore it is important to understand the effect of the previously mentioned two parameters on the physical and chemical properties of biodiesel such as the calorific value, flash point, carbon residue $\%$, ash $\%$, pour point, cetane index, viscosity, volatility and oxidative stability. This is necessary to be able to select the most suitable feedstock required to optimize the benefits of biodiesel [13-15].

The aim of this study was to explore the influence of the degree of unsaturation of fatty acids as well as the chain length of the feedstock used for the production of biodiesel on its properties as a fuel as well as its stability during storage. The results of this work could be a guide for determining the feedstock or their blends for the production of biodiesel.

\section{Materials}

\section{Experimental}

Two types of oils have been used in this study being palm oil and linseed oil obtained from the local market in Egypt. The first oil was selected as being rich in saturated fatty acids while the latter was rich in unsaturated fatty acids. Both oils have been analyzed for their fatty acid composition using gas liquid chromatography according to AOCS Official Methods [16]. The fatty acid compositions of the two oils are listed in Table 1.

The two oils were trans-esterified with methanol to yield biodiesel and the products of esterification have been then assessed as fuels for diesel engines according to their fuel properties, their oxidative stability as well as the performance of a diesel engine when run using biodiesel compared to regular diesel.

\section{Transesterification of palm and linseed oils}

Transesterification of palm and linseed oils was performed using methanol in presence of sulfuric acid as a catalyst at a percentage of three percent of the mixture weight .About six moles of alcohol were used for each mole of oil .The reaction progress was followed during the reaction using thin layer chromatography until completed as described by Megahed [17].

Egypt. J. Chem. 60, No. 1 (2017) 
Table 1. Fatty acid composition of palm and linseed oils.

\begin{tabular}{|l|c|c|}
\hline Fatty acids & Palm Oil & Linseed oil \\
\hline C14:0 & 1.0 & 0.0 \\
\hline C16:0 & 41.2 & 6.6 \\
\hline C18:0 & 3.3 & 3.4 \\
\hline C20:0 & 0.4 & 0.0 \\
\hline$\Sigma$ SFA & 45.9 & 10.0 \\
\hline C18:1 & 41.9 & 20.3 \\
\hline$\Sigma$ MUFA & 41.9 & 20.3 \\
\hline C18:2 & 11.9 & 15.3 \\
\hline C18:3 & 0.3 & 54.4 \\
\hline$\Sigma$ PUFA & 12.2 & 69.8 \\
\hline PUFA/SFA & 0.006 & 6.98 \\
\hline
\end{tabular}

$\Sigma \mathrm{SFA}=$ total saturated fatty acids

$\Sigma$ MUFA $=$ total mono unsaturated fatty acids

$\Sigma$ PUFA $=$ total poly unsaturated fatty acids

Evaluation of the fuel properties of the trans-esterified products

The trans-esterified products were then evaluated for their fuel properties as compared to regular diesel fuel using ASTM methods. They have been determined in the central analytical lab at the Egyptian Petroleum Research Institute, EPRI, Nasr City, Cairo following the standard methods of analysis, ASTM [18]. These include the calorific value (ASTM D-224), Flash point (ASTM D-93), carbon residue (ASTM D-189), ash\% (ASTM D-482) sulfur \% (ASTM D-4294), pour point (ASTM D-9), Kinematic viscosity (ASTM D-445) and density (ASTM D-4052).

Oxidative stability of the products obtained by transesterification of palm and linseed oils.

Rancimat 673 (Metrohm Co., Herisou, Switzerland), was used to determine the oxidative stability of the two biodiesels according to Rancimat method as described by Fatemi and Hammond [19]. A stream of air at a flow rate of $20 \mathrm{~L} / \mathrm{hr}$ was bubbled through the oil at $100{ }^{\circ} \mathrm{C}$. The volatile degradation products were trapped in distilled water in a second vessel, causing an increase in water conductivity. This instrument measures the induction period (IP) whereby the higher the IP value is the more stable the oil to oxidation.

\section{Engine testing using biodiesel}

The prepared biodiesel fuel has been evaluated according to the performance of a diesel engine operated using a 50\% blend of biodiesel with regular diesel fuel as compared to that using regular diesel fuel (solar). Engine testing has been conducted on a direct injection four strokes, four cylinders diesel engine $\left(\right.$ capacity $\left.1931 \mathrm{~cm}^{3}\right)$. A schematic layout of the experimental set-up used is described in Fig. 1. The instruments and measuring devices used in this set-up include: 
1- Hydraulic dynamometer which is essentially a torque measuring device

2- Tachometer and stroboscope which are rpm measuring devices.

3- Thermocouples to measure the temperature of the cooling water, inlet and exit as well as the temperature of the exhaust.

4- Air tank and orifice meter which is used to calculate the air flow rate.

5- Fuel tank as well as a fuel metering system

The experiments were carried at a constant speed of $1250 \mathrm{rpm}$. Five experimental runs were made using each fuel at different loads being; zero, 15, 40, 65 and $75 \mathrm{Nm}$. In each run, the following readings were recorded for performance evaluation:

1- Dynamometer reading (load) and engine rpm.

2- Fuel flow rate as well as air flow rate.

3 - The cooling water flow rate and temperature rise.

4- Exhaust temperature

On the basis of these readings, the performance parameters of the engine can be estimated which include:

1- Brake specific fuel consumption, BSFC, (gm/Kw.hr),

2- Brake thermal efficiency (\%),

3- Indicated specific fuel consumption, ISFC (gm/Kw.hr)

4- Indicated thermal efficiency (\%),

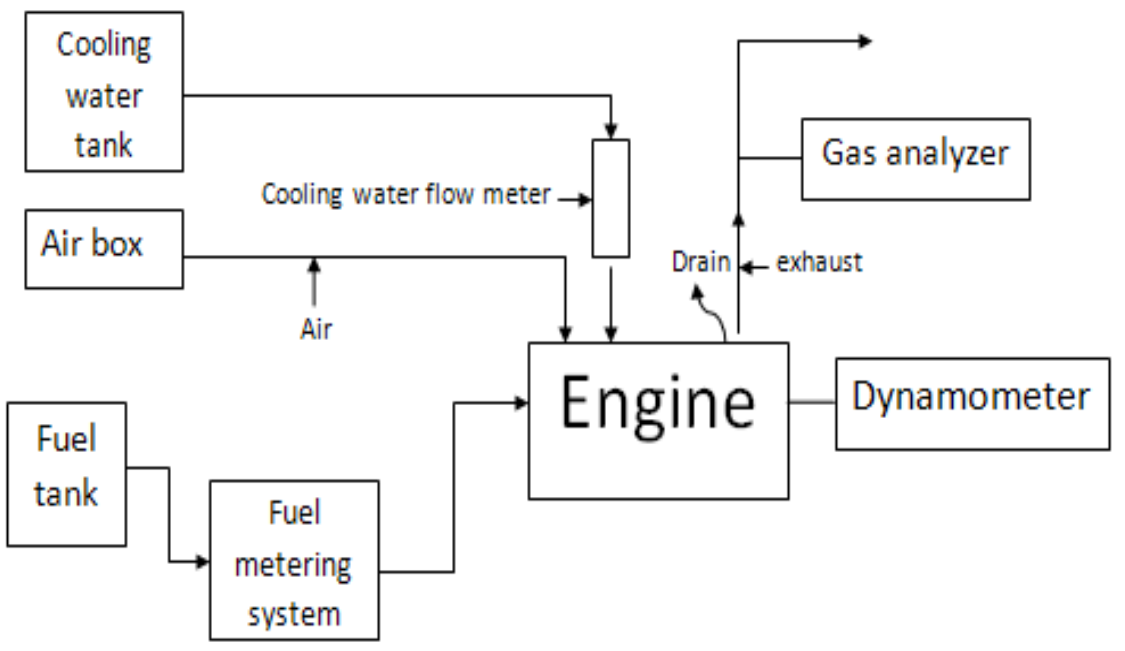

Fig. 1. Experimental setup.

Egypt. J. Chem. 60, No. 1 (2017) 


\section{Results}

\section{Fuel properties of biodiesel compared to regular diesel}

Table 2 lists the properties of biodiesel produced using linseed and palm oils as compared to regular diesel fuel. These include the density, kinematic viscosity, pour point, sulfur $\%$, ash $\%$, carbon residue $\%$, cetane index, flash point , calorific value, distillation characteristics as well as the induction period (hr), of both biodiesels as determined by Rancimat test. It is obvious that biodiesels produced by transesterification of both types of oils are more viscous than regular diesel fuel. It follows that their atomization in the engine would occur less efficiently with expected problems of carbon deposition in the engine due to inefficient combustion. Also, the calorific value of each of the two biodiesel products is less than that of regular diesel being about $88 \%$ and $80 \%$ of that of regular diesel in case of linseed biodiesel and palm oil biodiesel respectively. This means that the expected output power upon combustion of biodiesel will be lower. However, they are more volatile than regular diesel according to the results of ASTM distillation which makes their combustion easier. Moreover, both biodiesels have the advantage of being completely free of sulfur. Sulfur oxidation during fuel combustion would release corrosive oxides which have an adverse impact on the environment and the engine components as well. In view of that finding, it can be stated that biodiesel is more environment friendly than petrol fuel not only because it reduces carbon dioxide emissions but also because it eliminates the emission of corrosive sulfur oxides.

The results presented in Table 2 show also that biodiesel produced by transesterification of highly unsaturated linseed oil have two advantages over that produced by trans-esterification of the highly saturated palm oil being more volatile with higher heating value. However, the flash point of the former (linseed biodiesel) is lower than that of the latter (palm oil biodiesel) which makes it less safe during handling and storage. Moreover, linseed biodiesel is much less stable to oxidation than palm oil biodiesel whereby the induction period measured by Rancimat test was 40.6 hours in case of palm biodiesel compared to 2.8 hours in case of linseed biodiesel. This result is quite expected since the ratio between total poly unsaturated fatty acids and total saturated fatty acids, PUFA/SFA, was 6.98 in the case of linseed oil compared to 0.006 in case of palm oil as in Table 1.

\section{Results of engine testing}

The results of the diesel engine running using regular diesel fuel and its $50 \%$ blend with palm biodiesel and linseed biodiesel are listed in Tables 3-8. It can be seen that the brake specific fuel consumption, BSFC, has been increased by blending with regular diesel with biodiesel. At a brake power $9.8 \mathrm{Kw}$, it has been increased from $285 \mathrm{gm} / \mathrm{Kw}$ hr to about $320 \mathrm{gm} / \mathrm{Kw} \mathrm{hr}$. This is a quite expected result since the heating value of biodiesel is lower than that of regular diesel. The estimated brake thermal efficiency was $30 \%$ using regular diesel compared to $27 \%$ if it was blended with $50 \%$ biodiesel. The variations in the composition of the exhaust by blending regular diesel with biodiesel are not noticeable. However 
TABLE 2 - Properties of linseed and palm oil biodiesels compared to regular diesel.

\begin{tabular}{|c|c|c|c|c|}
\hline Experiment & Method & $\begin{array}{c}\text { Regular } \\
\text { diesel }\end{array}$ & $\begin{array}{c}\text { Biodiesel } \\
\text { of linseed } \\
\text { oil }\end{array}$ & $\begin{array}{c}\text { Biodiesel } \\
\text { of palm } \\
\text { oil }\end{array}$ \\
\hline Density, @ $15.56{ }^{\circ} \mathrm{C}$ & \multirow{3}{*}{$\underline{\text { ASTMD-1298 }}$} & 0.8543 & 0.8811 & 0.8700 \\
\hline Specific Gravity & & 0.8551 & 0.8896 & 0.8709 \\
\hline API gravity @ $60^{\circ} \mathrm{F}$ & & 33.97 & 28.94 & 30.98 \\
\hline Kinematic viscosity, cSt, @ $40^{\circ} \mathrm{C}$ & ASTM D-445 & 2.64 & 5.94 & 3.73 \\
\hline Pour point, ${ }^{\circ} \mathrm{C}$ & ASTM D-97 & 3 & -9 & -3 \\
\hline Total Sulphur, wt \% & ASTM D-4294 & 0.68 & Nil & Nil \\
\hline Ash content, wt $\%$ & ASTM D-482 & 0.006 & 0.001 & Nil \\
\hline Carbon residue, wt $\%$ & ASTM D-189 & 0.016 & Nil & Nil \\
\hline Cetane index & ASTM D-976 & 47 & 31.5 & 34 \\
\hline Flash point, ${ }^{\circ} \mathrm{C}$ & ASTM D-93 & 88 & 69 & 103 \\
\hline Gross Calorific value cal/g & \multirow{2}{*}{ ASTM D-224 } & 11357 & 9936 & 8968 \\
\hline Net Calorific value cal/g & & 10741 & 9340 & 8364 \\
\hline Induction period, hr at $100^{\circ} \mathrm{C}$ & Rancimat test & - & 2.8 & 40.6 \\
\hline Distillation & \multirow{14}{*}{ ASTM D-86 } & & & \\
\hline 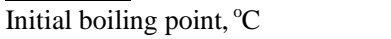 & & 170 & 90 & 90 \\
\hline $10 \mathrm{ml}$ & & 205 & 190 & 190 \\
\hline $20 \mathrm{ml}$ & & 235 & 210 & 220 \\
\hline $30 \mathrm{ml}$ & & 264 & 225 & 225 \\
\hline $40 \mathrm{ml}$ & & 275 & 240 & 230 \\
\hline $50 \mathrm{ml}$ & & 278 & 245 & 240 \\
\hline $60 \mathrm{ml}$ & & 300 & 245 & 260 \\
\hline $70 \mathrm{ml}$ & & 310 & 245 & 270 \\
\hline $80 \mathrm{ml}$ & & 315 & 245 & 280 \\
\hline $90 \mathrm{ml}$ & & 322 & 260 & 300 \\
\hline Recovery, ml & & 91 & 91 & 91 \\
\hline Residue, ml & & 8 & 7 & 7 \\
\hline Loss $\%$ & & 1 & 2 & 2 \\
\hline
\end{tabular}

such blending effects an increase of the temperature of the exhaust of about $10^{\circ} \mathrm{C}$ which can be attributed to the increase in the rate of fuel consumption by biodiesel blending.

TABLE 3. Results of Diesel engine running using regular diesel fuel.

\begin{tabular}{|l|c|c|c|c|c|}
\hline Brake power (KW) & 0 & 1.9 & 5.2 & 8.5 & 9.8 \\
\hline Indicated power (KW) & 5.8 & 7.8 & 11.1 & 14.3 & 15.6 \\
\hline Mechanical efficiency (\%) & 0 & 25.1 & 47.1 & 59.2 & 62.6 \\
\hline BSFC (gm/Kw.hr) & -- & 642.8 & 352.7 & 291.8 & 285.6 \\
\hline ISFC (gm/Kw.hr) & 184.5 & 161.2 & 166.4 & 172.7 & 178.8 \\
\hline BMEP (Kpa) & 0 & 97.6 & 260.3 & 422.9 & 488.0 \\
\hline IMEP (Kpa) & 291.4 & 389.0 & 551.7 & 714.3 & 779.4 \\
\hline $\begin{array}{l}\text { Brake thermal efficiency } \\
\text { (\%) }\end{array}$ & 0 & 13.3 & 24.3 & 29.3 & 30.0 \\
\hline $\begin{array}{l}\text { Indicated thermal } \\
\text { efficiency (\%) }\end{array}$ & 46.4 & 53.1 & 51.5 & 49.6 & 47.9 \\
\hline A/F ratio & 54.9 & 47.0 & 32.1 & 23.9 & 21.1 \\
\hline Volumetric efficiency (\%) & 72.0 & 72.0 & 72.0 & 72.0 & 72.0 \\
\hline
\end{tabular}

Egypt. J. Chem. 60, No. 1 (2017) 
TABLE 4. Exhaust temperature and composition of Diesel engine running using regular diesel fuel.

\begin{tabular}{|c|c|c|c|c|c|c|}
\hline \multicolumn{2}{|c|}{ Brake power $(\mathbf{K W})$} & 0 & 1.9 & 5.2 & 8.5 & 9.8 \\
\hline \multicolumn{2}{|c|}{ Exhaust Temp $\left({ }^{\circ} \mathrm{C}\right)$} & 113.9 & 143.1 & 206.2 & 267 & 307.2 \\
\hline \multirow{5}{*}{ Emissions } & $\mathrm{O}_{2}(\%)$ & 16.8 & 15.6 & 13.4 & 10.7 & 9.4 \\
\hline & $\begin{array}{c}\mathrm{CO} \\
(\mathrm{ppm})\end{array}$ & 1606 & 1318 & 1256 & 1445 & 1489 \\
\hline & $\mathrm{CO}_{2}(\%)$ & 0 & 3.4 & 4.3 & 5.8 & 7.7 \\
\hline & $\begin{array}{c}\mathrm{SO}_{2} \\
(\mathrm{ppm})\end{array}$ & 348 & 167 & 142 & 140 & 170 \\
\hline & $\begin{array}{l}\mathrm{NO}_{\mathrm{x}} \\
(\mathrm{ppm})\end{array}$ & 89 & 512 & 540 & 794 & 714 \\
\hline
\end{tabular}

TABLE 5. Results of Diesel engine running using $50 \%$ blend of palm biodiesel with regular diesel fuel.

\begin{tabular}{|l|c|c|c|c|c|}
\hline Brake power (KW) & 0 & 1.9 & 5.2 & 8.5 & 9.8 \\
\hline Indicated power (KW) & 4.3 & 6.3 & 9.6 & 12.8 & 14.1 \\
\hline $\begin{array}{l}\text { Mechanical efficiency } \\
(\%)\end{array}$ & 0 & 30.9 & 54.4 & 66.0 & 69.1 \\
\hline BSFC (gm/Kw.hr) & -- & 754.2 & 368.7 & 358.5 & 317.0 \\
\hline ISFC (gm/Kw.hr) & 258.1 & 233.5 & 200.8 & 236.7 & 219.3 \\
\hline BMEP (Kpa) & 0 & 97.6 & 260.2 & 422.9 & 488.0 \\
\hline IMEP (Kpa) & 217.5 & 315.1 & 477.8 & 640.5 & 705.5 \\
\hline $\begin{array}{l}\text { Brake thermal } \\
\text { efficiency (\%) }\end{array}$ & 0 & 11.3 & 23.2 & 23.9 & 27.0 \\
\hline $\begin{array}{l}\text { Indicated thermal } \\
\text { efficiency (\%) }\end{array}$ & 33.2 & 36.7 & 42.7 & 36.2 & 39.1 \\
\hline A/F ratio & 55.1 & 42.1 & 32.2 & 20.3 & 19.9 \\
\hline $\begin{array}{l}\text { Volumetric efficiency } \\
\text { (\%) }\end{array}$ & 74.6 & 74.6 & 74.6 & 74.6 & 74.6 \\
\hline
\end{tabular}

TABLE 6. Exhaust temperature and composition of Diesel engine running using $50 \%$ blend of palm biodiesel with regular diesel fuel.

\begin{tabular}{|c|c|c|c|c|c|c|}
\hline \multicolumn{2}{|c|}{ Brake power (KW) } & 0 & 1.9 & 5.2 & 8.5 & 9.8 \\
\hline \multicolumn{2}{|c|}{ Exhaust Temp $\left({ }^{\circ} \mathrm{C}\right)$} & 113.2 & 143.5 & 201.9 & 278 & 320.1 \\
\hline \multirow{5}{*}{ Emissions } & $\mathrm{O}_{2}(\%)$ & 17.2 & 16.1 & 14.2 & 11.6 & 10.2 \\
\hline & $\begin{array}{c}\mathrm{CO} \\
(\mathrm{ppm})\end{array}$ & 1585 & 1232 & 1692 & 1904 & 1887 \\
\hline & $\mathrm{CO}_{2}(\%)$ & 5.6 & 2.9 & 0 & 7.2 & 7.8 \\
\hline & $\begin{array}{c}\mathrm{SO}_{2} \\
(\mathrm{ppm})\end{array}$ & 340 & 222 & 196 & 159 & 134 \\
\hline & $\begin{array}{l}\mathrm{NO}_{\mathrm{x}} \\
(\mathrm{ppm})\end{array}$ & 57 & 161 & 454 & 693 & 666 \\
\hline
\end{tabular}


TABLE 7. Results of Diesel engine running using $50 \%$ blend of linseed biodiesel with regular diesel fuel.

\begin{tabular}{|l|c|c|c|c|c|}
\hline Brake power (KW) & 0 & 1.9 & 5.2 & 8.5 & 9.8 \\
\hline $\begin{array}{l}\text { Indicated power } \\
\text { (KW) }\end{array}$ & 5.5 & 7.5 & 10.7 & 14.0 & 15.3 \\
\hline $\begin{array}{l}\text { Mechanical } \\
\text { efficiency (\%) }\end{array}$ & 0 & 26.1 & 48.5 & 60.4 & 63.8 \\
\hline BSFC (gm/Kw.hr) & -- & 726.1 & 397.4 & 323.1 & 313.6 \\
\hline ISFC (gm/Kw.hr) & 200.7 & 189.5 & 192.7 & 195.4 & 200.2 \\
\hline BMEP (Kpa) & 0 & 97.6 & 260.3 & 422.9 & 488.0 \\
\hline IMEP (Kpa) & 276.3 & 373.9 & 536.6 & 699.3 & 764.3 \\
\hline $\begin{array}{l}\text { Brake thermal } \\
\text { efficiency (\%) }\end{array}$ & 0 & 11.8 & 21.5 & 26.5 & 27.3 \\
\hline $\begin{array}{l}\text { Indicated thermal } \\
\text { efficiency (\%) }\end{array}$ & 42.7 & 45.2 & 44.4 & 43.8 & 42.7 \\
\hline A/F ratio & 55.7 & 43.6 & 29.9 & 22.6 & 20.2 \\
\hline $\begin{array}{l}\text { Volumetric } \\
\text { efficiency (\%) }\end{array}$ & 74.6 & 74.6 & 74.6 & 74.6 & 74.6 \\
\hline
\end{tabular}

TABLE 8. Exhaust temperature and composition of Diesel engine running using $50 \%$ blend of linseed biodiesel with regular diesel fuel.

\begin{tabular}{|c|c|c|c|c|c|c|}
\hline \multicolumn{2}{|c|}{ Brake power (KW) } & 0 & 1.9 & 5.2 & 8.5 & 9.8 \\
\hline \multicolumn{2}{|c|}{ Exhaust Temp $\left({ }^{\circ} \mathrm{C}\right)$} & 111.8 & 142.6 & 198 & 274.5 & 313.4 \\
\hline \multirow{5}{*}{ Emissions } & $\mathrm{O}_{2}(\%)$ & 17.2 & 16 & 13.9 & 11.3 & 10.1 \\
\hline & $\mathrm{CO}(\mathrm{ppm})$ & 1953 & 1492 & 1146 & 1178 & 1228 \\
\hline & $\begin{array}{l}\mathrm{CO}_{2}(\%)- \\
\text { calculated }\end{array}$ & 0 & 2.9 & 3.9 & 6.7 & 7.4 \\
\hline & $\mathrm{SO}_{2}(\mathrm{ppm})$ & 484 & 315 & 141 & 146 & 166 \\
\hline & $\mathrm{NO}_{\mathrm{x}}(\mathrm{ppm})$ & 33 & 133 & 418 & 753 & 781 \\
\hline
\end{tabular}

\section{References}

1. Zaher, F.A., Vegetable oils as alternative fuel for diesel engines: A review, Grasas $Y$ Aceites, 41, 82 - 91 (1990).

2. Zaher, F.A., Megahed, O.A. and El Kinawy, O.S., Esters of sunflower oil as an alternative fuel for diesel engines, Energy Sources, 25, 1015-1022, (2003).

3. Zaher, F.A., Megahed, O.A. and El Kinawy, O.S., Utilization of used frying oil as diesel engine fuel, Energy Sources, 25, 819-826, (2003).

4. Zaher, F.A., Megahed, O.A., Abdallah, R.I. and Nabil, D., Rapeseed oil esters as diesel engine fuel , Energy Sources, 26, 119-126 ( 2004).

5. Demirbas A., Importance of biodiesel as transportation fuel. Energy Policy, 35, 46614670 (2007).

6. Knothe G., Designer" biodiesel: optimizing fatty ester composition to improve fuel properties. Energy \& Fuels, 22, 1358-1364 (2008). 
7. El Kinawy, O.S. and Zaher, F.A., Studies on esterification kinetics of short chain alcohols with fatty acids to produce biodiesel fuel, Energy Sources, 34, 662-670 (2012).

8. Zaher, F.A., El Kinawy, O.S. and Abdallah, R., The esterification of jatropha oil using different short chain alcohols to produce esters to be used as biodiesel fuel. Energy Sources, 34, 2214-2219 (2012).

9. Soliman, H.M., El Kinawy, O.S. and Zaher, F.A., Production of biodiesel fuel from the industrial wastes of the oil and soap industrial sector, J. Appl. Sci. Res., 9 (3) 2188-2195 (2013).

10. Demirbas, A., Biodiesel from vegetable oils via transesterification in supercritical methanol. Energy Conversion and Management, 43, 2349-2356 (2002).

11. Hawash, S., Kamal, N., Zaher, F.A., El Kinawy, O.S. and El-Diwani, G., Biodiesel Fuel from jatropha oil via non-catalytic supercritical methanol transesterification. Fuel, 88, 579-582 (2009)

12. Mostafizur-Rahman Md., Influences of biodiesel chemical compositions and physical properties on engine exhaust particle emissions. Science and Engineering Faculty (SEF) Queensland University of Technology (QUT) (2015).

13. Saxenaa P., Jawaleb S. and Joshipura M.H.X., A review on prediction of properties of biodiesel and blends of biodiesel. Procedia Engineering, 51, 395 - 402 (2013).

14. Wakil M.A., Kalam M.A., Masjuki H.H., Atabani A.E., and Rizwanul Fattah I.M., Influence of biodiesel blending on physicochemical properties and importance of mathematical model for predicting the properties of biodiesel blend .Energy Conversion and Management, 94, 51-67 (2015).

15. Saxena P., Mevada S.V. and Joshipura. M.H., Prediction of cold flow properties of Biodiesel. Journal of Engineering and Technology, 5 (1) 1-4 (2016).

16. Mehlenbacher, V., T.H. Hopper, E.M. Sallee and W.E. Link (Eds) Official Methods and Recommended Practices of the American Oil Chemists' Society, 5th Edn., American Oil Chemist's Society, USA (2007).

17. Megahed, O.A., Utilization of Rice Bran Oil for the Production of Diesel Engine Fuel, Ph. D. Thesis, Cairo University (1996).

18. ASTM Annual Book of Standards Petroleum Products and Lubricants, section 5, Vol. (5.01-5.03), American Society of Testing and Materials, Philadelphia, USA (1995).

19. Fatemi S.H., Hammond E.G., Analysis of oleate, linoleate and linolenate hydroperoxides in oxidized ester mixtures. Lipids 15, 379-385 (1980)

(Received 22/2/2017;

Accepted 27/3/2017)

Egypt. J. Chem. 60, No. 1 (2017) 


\title{
وقود حيوي بديل لوقود الديزل التقليدي باستخدام الزيوت النباتية المشبعة وعديدة عدم التشبع التويل \\ فريال عباس زاهر، أميمة عبدالسلام القناوى، هناء محمد سليمان، عادل جبر \\ عبدالزازق \\ قسم الزيوث و الدهون، المركز القومى للبحوث، 33 ش البحوث، الدقى،الجيزة، مصر.
}

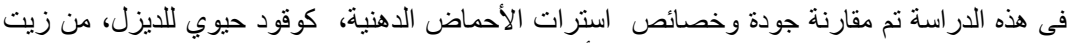

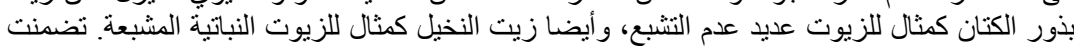

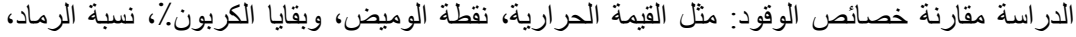

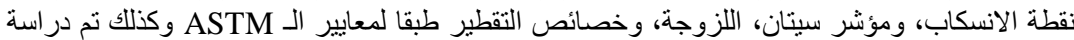

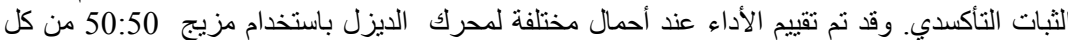
منهم مع الديزل العادى مقارنة مع وقود الديزل التقاه لتقليدى منفردا.
\end{abstract}

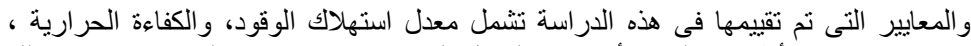

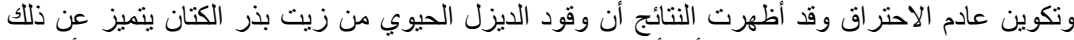

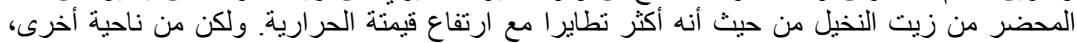

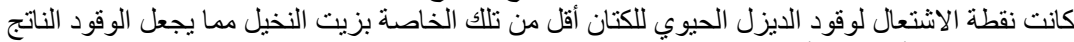

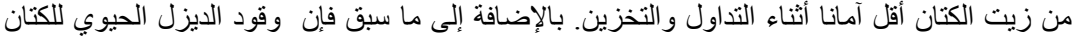

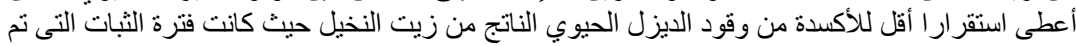

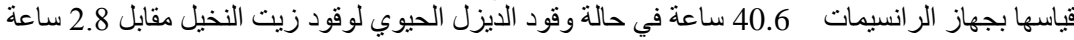

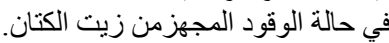

وقد أظهرت نتائج الدراسة أن تشبع الأحماض الدهنية لوقود الديزل الحيوي من عدمه لا يؤثر

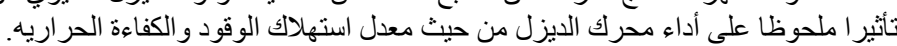

